\title{
Increasing the Performance of Agricultural Holdings in Romania - an Imperative for their Management
}

\author{
David-Nicolae CRECANĂ ${ }^{1}$ \\ Cornel-Dumitru CRECANĂ $\breve{a}^{2}$
}

\begin{abstract}
As a member state of the European Union, Romania consolidates from year to year its position in the agricultural business performance area, especially due to the increase in the share of agricultural land for organic farming.

Romania's long-term development strategy necessarily involves increasing the economic performance of Romanian agriculture alongside the increase in the living standards of the rural population.

This research starts from a current radiography of Romanian agriculture and aims at new ways to increase the performances of the Romanian agricultural farms in the conditions of general economic development.

An adequate management of the Romanian agricultural farms is imperative, along with the effective support of the European Union offered to the Romanian agriculture.

The increase in the incomes obtained from Romania's agriculture can be achieved by a new approach to the size and economic size of agricultural farms, but also by transforming them into organic farms.

Sustainable development of agricultural businesses is thus a priority.
\end{abstract}

Keywords: land use, holding dimension, economic size, organic farming, sustainable development, financial sustainability.

JEL classification: O11, O13, Q01, Q15, Q51, Q53, Q57, M21.

DOI: $10.24818 /$ RMCI.2019.2.112

\section{Introduction}

The Romanian agricultural competiveness is a debate full topic in the context of the late sectorial reforms during the country accession and convergence to the EU-28 agricultural model. In this context, agro-food trade competitiveness as a vital component of a total economic competitiveness requires a more thorough approach in the process of land use valuing potential. Understanding the agricultural competitiveness improves the inland agricultural structure development (Popescu et al., 2017).

In Romania, agriculture is the turning point for any medium and long-term development strategy of the national economy, the orientation of Romanian or foreign investors to this field being able to stimulate the appropriate development

1 David-Nicolae Crecană, Bucharest University of Economic Studies, e-mail: crecanadavid @ gmail.com

2 Cornel-Dumitru Crecană, Bucharest University of Economic Studies, e-mail: cornel.crecana @ cig.ase.ro

112 Review of International Comparative Management

Volume 20, Issue 2, May 2019 
of the industries that feed the agriculture with various raw materials and utilities of the food industry, all of which contribute to the food security of the country and to the obtaining of important amounts from the export sales of the surplus.

Economic growth involves some models of changing the economic structure in several sectors; these models have been a good foundation of the development economy for decades. Two variables are those that receive a special emphasis in the literature of structural transformation: the share of gross domestic product (GDP as a measure of aggregate income) and of the economically active population (as a measure of its work) both measures tend to decrease with GDP growth (Tomich et al., 2019).

In Romania, the limited financing possibilities of the agricultural producers have led to an increase in the importance of European funds for agriculture (Istudor et al., 2015).

Agriculture uses resources provided by the industry, and any imbalance in this industry is entirely felt by it. The globalization of agricultural markets poses obvious difficulties for agricultural businesses, as the probability of production is added to the likelihood of the sale.

The peculiarities that fundamentally distinguish agricultural activity from industrial or purely commercial activity must be considered with all responsibility by the main decision-makers in this field of activity (the ministry, government agencies), especially because any unrealistic decision will affect seriously the food security of this country, and in the end all activities will suffer, including industrial activities.

\section{The situation of Romanian agriculture in $\mathbf{2 0 1 6}$}

In Romania the number of farms by utilised agricultural area are shown in the following table:

Table 1. Agricultural holdings in Romania, by number, by utilised agricultural area, 2013-2016

\begin{tabular}{|c|c|r|r|r|}
\hline \multirow{2}{*}{ Indicators } & \multirow{2}{*}{ M.U. } & \multicolumn{2}{|c|}{ Total agricultural holding } & $\mathbf{2 0 1 6 / 2 0 1 3}$ \\
\cline { 3 - 5 } & & $\mathbf{2 0 1 3}$ & $\mathbf{2 0 1 6}$ & \% \\
\hline $\begin{array}{l}\text { Number of agricultural } \\
\text { holdings }\end{array}$ & thou & 3630 & 3422 & $94.27 \%$ \\
\hline Utilised agricultural area & thou ha & 13056 & 12503 & $95.76 \%$ \\
\hline arable land & thou ha & 8198 & 7814 & $95.32 \%$ \\
\hline pastures and meadows & thou ha & 4398 & 4246 & $96.54 \%$ \\
\hline permanent crops & thou ha & 302 & 301 & $99.67 \%$ \\
\hline kitchen gardens & thou ha & 158 & 142 & $89.87 \%$ \\
\hline $\begin{array}{l}\text { Average utilised agricultural } \\
\text { area per agricultural holding }\end{array}$ & ha & 3.6 & 3.65 & $101.39 \%$ \\
\hline
\end{tabular}

Source: Structural Survey in Agriculture INSSE

The number of agricultural holdings decreased in 2016 compared to 2013 by $5.7 \%$ and the agricultural area used for agricultural holdings was $4.2 \%$ lower in 2016 compared to 2013. 
In the structure, the largest decrease in the agricultural area used was in the kitchen gardens, respectively $10.1 \%$ lower in 2016 compared to 2013.

As a share of total EU-28, the used agricultural area was 7.2\% in 2016, while the number of agricultural holdings accounted for $32.7 \%$ of the EU-28 total.

The personnel employed in agriculture was 1.960 .300 in 2016.

Young farmers (under 40 years old) represented $7.4 \%$ share of all farm managers, in 2016.

Female farmers represented 33.6\% share of all farm manager, in 2016.

Farmers with full agricultural training represented $0.4 \%$ share of all farm managers, in 2016.

In Romania agricultural holding, by size classes of utilised agricultural area, by destination of agricultural are shown in the following table:

Table 2. Agricultural holdings in Romania, by size classes of utilised agricultural area, by destination of agricultural production, 2016

\begin{tabular}{|c|c|c|}
\hline \multirow{2}{*}{$\begin{array}{l}\text { Size classes of utilised } \\
\text { agricultural area }\end{array}$} & \multicolumn{2}{|c|}{ Destination of agricultural production } \\
\hline & $\begin{array}{r}\text { For own consumption, } \\
\text { more than } 50 \%{ }^{*}\end{array}$ & $\begin{array}{r}\text { Direct sale, } \\
\text { more than } 50 \%\end{array}$ \\
\hline & \multicolumn{2}{|c|}{ Utilised agricultural area (hectares) } \\
\hline \multicolumn{3}{|l|}{$\begin{array}{l}\text { Size classes of utilised } \\
\text { agricultural area (hectares) }\end{array}$} \\
\hline Under 0.1 & 17417.43 & 545.21 \\
\hline $0,1-0,3$ & 92270.68 & 4765.40 \\
\hline $0,3-0,5$ & 105445.66 & 6137.44 \\
\hline $0,5-1$ & 372427.47 & 24998.15 \\
\hline $1-2$ & 797964.33 & 75622.66 \\
\hline $2-5$ & 1652845.71 & 307654.78 \\
\hline $5-10$ & 816376.20 & 370268.06 \\
\hline $10-20$ & 191587.75 & 288228.21 \\
\hline $20-30$ & 26734.11 & 144326.21 \\
\hline $30-50$ & 12866.88 & 172651.28 \\
\hline $50-100$ & 6646.54 & 226941.93 \\
\hline 100 and over & 1005.50 & 1692671.75 \\
\hline TOTAL & 4093588.26 & 3314811.08 \\
\hline
\end{tabular}

The number of very small agricultural holdings, which have used a farm surface up to 1 hectare decreased in 2016 compared to 2013 by 173 thousand agricultural holdings, respectively with $8.9 \%$.

More than $61 \%$ of the agricultural area used is owned by those using it.

In Romania agricultural output (constant prices) are shown in the following table: 
Table 3. Agricultural output in Romania, 2015 - 2016

\begin{tabular}{|c|c|c|c|c|c|}
\hline \multirow{2}{*}{$\begin{array}{l}\text { Output components } \\
\text { (constant prices) }\end{array}$} & 2015 & 2016 & \multirow{2}{*}{\begin{tabular}{|c|}
2015 \\
$\%$ of total
\end{tabular}} & \multirow{2}{*}{\begin{tabular}{|c|}
2016 \\
$\%$ of total
\end{tabular}} & \multirow{2}{*}{$\begin{array}{c}\text { Change } \\
\% \text { of total }\end{array}$} \\
\hline & \multicolumn{2}{|c|}{ Million EUR } & & & \\
\hline 1. Cereals: & 2981 & 3068 & $23.99 \%$ & $24.92 \%$ & $0.93 \%$ \\
\hline Wheat and spelt & 1195 & 1059 & $9.62 \%$ & $8.60 \%$ & $-1.01 \%$ \\
\hline Rye and meslin & 4 & 3 & $0.03 \%$ & $0.02 \%$ & $-0.01 \%$ \\
\hline Barley & 284 & 287 & $2.29 \%$ & $2.33 \%$ & $0.05 \%$ \\
\hline $\begin{array}{l}\text { Oats and summer cereal } \\
\text { mixtures }\end{array}$ & 63 & 65 & $0.51 \%$ & $0.53 \%$ & $0.02 \%$ \\
\hline Grain maize & 1395 & 1614 & $11.23 \%$ & $13.11 \%$ & $1.89 \%$ \\
\hline Rice & 10 & 9 & $0.08 \%$ & $0.07 \%$ & $-0.01 \%$ \\
\hline Other cereals & 31 & 31 & $0.25 \%$ & $0.25 \%$ & $0.00 \%$ \\
\hline 2. Industrial crops: & 1001 & 1191 & $8.06 \%$ & $9.68 \%$ & $1.62 \%$ \\
\hline $\begin{array}{l}\text { Oil seeds and } \\
\text { oleaginous fruits }\end{array}$ & 895 & 1085 & $7.20 \%$ & $8.81 \%$ & $1.61 \%$ \\
\hline Protein crops & 30 & 42 & $0.24 \%$ & $0.34 \%$ & $0.10 \%$ \\
\hline Raw tobacco & 1 & 2 & $0.01 \%$ & $0.02 \%$ & $0.01 \%$ \\
\hline Sugar beet & 34 & 26 & $0.27 \%$ & $0.21 \%$ & $-0.06 \%$ \\
\hline Other industrial crops & 41 & 37 & $0.33 \%$ & $0.30 \%$ & $-0.03 \%$ \\
\hline Forage plants & 1147 & 1108 & $9.23 \%$ & $9.00 \%$ & $-0.23 \%$ \\
\hline $\begin{array}{l}\text { Vegetables and } \\
\text { horticultural products }\end{array}$ & 1911 & 1768 & $15.38 \%$ & $14.36 \%$ & $-1.02 \%$ \\
\hline Potatoes & 632 & 720 & $5.09 \%$ & $5.85 \%$ & $0.76 \%$ \\
\hline Fruits & 911 & 876 & $7.33 \%$ & $7.12 \%$ & $-0.21 \%$ \\
\hline Wine & 213 & 199 & $1.71 \%$ & $1.62 \%$ & $-0.10 \%$ \\
\hline Olive oil & $\mathbf{0}$ & $\mathbf{0}$ & $0.00 \%$ & $0.00 \%$ & $0.00 \%$ \\
\hline Other crop products & 16 & 16 & $0.13 \%$ & $0.13 \%$ & $0.00 \%$ \\
\hline Crop output $(1+2)$ & 8812 & 8946 & $70.92 \%$ & $72.68 \%$ & $1.76 \%$ \\
\hline 3. Animals: & 1704 & 1608 & $13.71 \%$ & $13.06 \%$ & $-0.65 \%$ \\
\hline Cattle & 298 & 292 & $2.40 \%$ & $2.37 \%$ & $-0.03 \%$ \\
\hline Pigs & 747 & 705 & $6.01 \%$ & $5.73 \%$ & $-0.28 \%$ \\
\hline Equines & 17 & 14 & $0.14 \%$ & $0.11 \%$ & $-0.02 \%$ \\
\hline Sheep and goats & 193 & 170 & $1.55 \%$ & $1.38 \%$ & $-0.17 \%$ \\
\hline Poultry & 450 & 426 & $3.62 \%$ & $3.46 \%$ & $-0.16 \%$ \\
\hline Other animals & 1 & 0 & $0.01 \%$ & $0.00 \%$ & $-0.01 \%$ \\
\hline 4. Animal products: & 1910 & 1755 & $15.37 \%$ & $14.26 \%$ & $-1.11 \%$ \\
\hline Milk & 941 & 887 & $7.57 \%$ & $7.21 \%$ & $-0.37 \%$ \\
\hline Eggs & 660 & 597 & $5.31 \%$ & $4.85 \%$ & $-0.46 \%$ \\
\hline Other animal products & 309 & 272 & $2.49 \%$ & $2.21 \%$ & $-0.28 \%$ \\
\hline Animal output (3+4) & 3614 & 3363 & $29.08 \%$ & $27.32 \%$ & $-1.76 \%$ \\
\hline
\end{tabular}




\begin{tabular}{|l|c|c|c|c|c|}
\hline \multirow{2}{*}{$\begin{array}{l}\text { Output components } \\
\text { (constant prices) }\end{array}$} & 2015 & 2016 & 2015 & 2016 & Change \\
\cline { 2 - 6 } & \multicolumn{2}{|c|}{ Million EUR } & \% of total & \% of total & \% of total \\
\hline $\begin{array}{l}\text { Agricultural goods } \\
\text { output }\end{array}$ & 12426 & 12309 & $100.00 \%$ & $100.00 \%$ & \\
\hline
\end{tabular}

Source: Eurostat, Economic Accounts for Agriculture (values at real producer prices).

Regarding the dynamics of the structure of agricultural production expressed in constant prices, in the period 2015-2016, we find the following:

- the share of vegetable production in total agricultural production increases from $70.92 \%$ to $72.68 \%$ by $1.76 \%$

- the share of animal production in total agricultural production decreases from $29.08 \%$ to $27.32 \%$ by $1.76 \%$

- animal products decline as a share in total agricultural production from $15.37 \%$ to $14.26 \%$ by $1.11 \%$.

In Romania agricultural income (constant prices) are shown in the following table:

Table 4. Agricultural income in Romania, 2015 - 2016

\begin{tabular}{|l|r|r|r|}
\hline \multirow{2}{*}{ Values at basic prices } & \multicolumn{1}{c|}{$\mathbf{2 0 1 5}$} & \multicolumn{1}{c|}{$\mathbf{2 0 1 6}$} & \multicolumn{1}{c|}{$\mathbf{2 0 1 6 / 2 0 1 5}$} \\
\cline { 2 - 4 } & \multicolumn{2}{|c|}{ Million EUR } & \multicolumn{1}{c|}{ Change } \\
\hline Output of the agricultural "industry": & $\mathbf{1 3 9 0 2}$ & $\mathbf{1 3 7 4 1}$ & $-1.2 \%$ \\
\hline Crop output & 8811 & 8947 & $1.5 \%$ \\
\hline Animal output: & 3614 & 3363 & $-6.9 \%$ \\
\hline Animals & 1704 & 1608 & $-5.6 \%$ \\
\hline Animal products & 1910 & 1755 & $-8.1 \%$ \\
\hline Agricultural services & 174 & 178 & $2.3 \%$ \\
\hline Secondary activities & 1303 & 1252 & $-3.9 \%$ \\
\hline - Intermediate consumption & $\mathbf{8 0 5 8}$ & $\mathbf{7 9 2 1}$ & $\mathbf{- 1 . 7 \%}$ \\
\hline = Gross value added at basic prices & $\mathbf{5 8 4 4}$ & $\mathbf{5 8 2 0}$ & $\mathbf{- 0 . 4 \%}$ \\
\hline - Consumption of fixed capital & 2202 & 2060 & $-6.4 \%$ \\
\hline - Taxes & 20 & 20 & $0.0 \%$ \\
\hline + Subsidies & 1417 & 2338 & $65.0 \%$ \\
\hline = Factor income & $\mathbf{5 0 4 0}$ & $\mathbf{6 0 7 9}$ & $\mathbf{2 0 . 6 \%}$ \\
\hline Agricultural income* (2010=100) & $\mathbf{1 2 1 . 6}$ & $\mathbf{1 1 9 . 1}$ & $\mathbf{- 2 . 1 \%}$ \\
\hline
\end{tabular}

Source: Eurostat, Economic Accounts for Agriculture (values at real prices; constant prices for Indicator A), (*) The so-called indicator A is the real net value added at factor cost of agriculture per annual work unit (AWU). The net value added at factor cost (factor income) is calculated by subtracting the consumption of fixed capital from gross value added at basic prices and adding the value of subsidies less taxes.

Income in agriculture declines by $20.1 \%$ in 2016 compared to 2015 due to the $1.2 \%$ decrease in agricultural production.

The reduction of agricultural production in 2016 compared to 2015 is due to the $6.9 \%$ decrease in animal production and secondary activities by $3.9 \%$.

In Romania agricultural input are shown in the following table: 
Table 5. Agricultural input in Romania, 2015 - 2016

\begin{tabular}{|l|r|r|r|}
\hline \multirow{2}{*}{\multicolumn{1}{|c|}{ Input components }} & $\mathbf{2 0 1 5}$ & $\mathbf{2 0 1 6}$ & $\mathbf{2 0 1 6 / 2 0 1 5}$ \\
\cline { 2 - 4 } & \multicolumn{2}{|c|}{ Million EUR } & \% Change \\
\hline Seeds and planting stock & 636 & 697 & $9.60 \%$ \\
\hline Energy & 1613 & 1671 & $3.60 \%$ \\
\hline Fertilisers and soil improvers & 535 & 582 & $8.70 \%$ \\
\hline Plant protection products & 229 & 271 & $18.00 \%$ \\
\hline Veterinary expenses & 296 & 250 & $-15.40 \%$ \\
\hline Feedingstuffs & 2270 & 2208 & $-2.70 \%$ \\
\hline Maintenance of materials & 408 & 429 & $5.00 \%$ \\
\hline Maintenance of buildings & 100 & 108 & $7.90 \%$ \\
\hline Agricultural services & 174 & 178 & $2.60 \%$ \\
\hline Other goods and services & 1768 & 1499 & $-15.20 \%$ \\
\hline Total intermediate consumption & $\mathbf{8 0 5 8}$ & $\mathbf{7 9 2 1}$ & $\mathbf{- 1 . 7 0 \%}$ \\
\hline Fixed capital consumption & & & $\mathbf{- 6 . 4 \%}$ \\
\hline Source: Eury & $\mathbf{2 2 0 2}$ & $\mathbf{2 0 6 0}$ & \\
\hline
\end{tabular}

Source: Eurostat, Economic Accounts for Agriculture, values at real basic prices $(2010=100)$

Total intermediate consumption declined by $1.7 \%$ in 2016 compared to 2015 , mainly due to $15.4 \%$ decrease in veterinary expenses and $12.5 \%$ to other goods and services.

Instead, spending on fertilizer and soil improvers increased by $18 \%$ in 2016 compared to 2015 , followed by seed and planting stock with a $9.6 \%$ increase in 2016 compared to 2015.

\section{The case of organic farms in Romania}

Farming in the European Union is undergoing an extensive process of transformation, the criteria for the sustainability of agricultural production and the quality of agricultural products being at the forefront.

Organic farming has potential to increase net returns, reduce the risks of crop failure and reduce environmental impacts. However, these advantages are shown to be site-dependent and organic farming might lead to soil nutrient depletion and decreasing yields, if the livestock density and manure production is insufficient (Vasile et al., 2015).

Maximizing agricultural output and, implicitly, earnings in conventional agricultural farms loses ground against growing organic farming.

Although it has begun as a niche business with luxury agricultural products for high income social categories, organic farming tends to be the norm at EU level.

In fact, the 2008 world economic crisis has been the maturity exam of organic farming, which managed to survive the crisis and even develop during the crisis. 
"Sustainable Intensification," which is now widely used to describe the future direction of agriculture and food production, is a way of meeting the challenges of global population growth, food security, resource conservation and climate change. While sustainability is being interpreted by some speculators in connection with increased production, with a more efficient but potentially higher use of inputs and technology, it is necessary and important to take into account environmental protection, including conservation and renewal natural capital and ecosystem services production Lampkin et al., 2015).

The trend at European level is to increase the share of organic farms in all agricultural holdings.

Organic agriculture's role will be determined by whether it can be or become economically competitive with conventional agriculture. This depends on productivity of organic agriculture, demand for its products, and on the extent to which consumer prices reflect costs of externalities associated with both production orientations, including costs of environmental and health externalities (Ponti et al., 2012).

According to Caron (et al., 2014) the transition to ecological intensification in agriculture is an intensive process of knowledge and should not be perceived as the promotion of old traditional practices.

The different conditions of agricultural production worldwide, as well as the development of infrastructure in rich and traditionally agricultural countries, may falter agriculture in poor countries. Integration of agricultural production activities with industrial processing of agricultural products can reduce the effects of seasonality and facilitate access to bank credit.

The performance of organic farms is directly dependent on:

1. natural production conditions

Natural production conditions imply obvious limits to agricultural activities (specialization according to relief, climate, land fertility, hydrographic network).

2. ways of financing and ensuring agricultural production

Consistency and probability of revenue generation do not allow agriculture to exist under industry-related, trade-related or service-related financing conditions.

Excessive interest rates imposed by the banking system, as well as the minimum risks provided by specialized institutions, can cause the bankruptcy of agricultural activities and the massive use of agricultural products.

3 . the solvable demand on the agricultural products market

Under ideal conditions to achieve agricultural output (in the quantities and qualities envisaged) the decisive factor in terms of profitability is the solvable demand on the agricultural products market.

In Romania, the number of agricultural holdings with used agricultural area, organic certificate, agricultural area undergoing transformation and organic livestock farming, according to the legal status of agricultural holdings is reflected in the following table:

118 Review of International Comparative Management

Volume 21, Issue 1, May 2019 
Table 6. Agricultural holdings with UAA organically certified, UAA under conversion and organic farming livestock, 2016

\begin{tabular}{|l|r|r|r|}
\hline Legal status of agricultural holdings & $\begin{array}{c}\text { agricultural area } \\
\text { organically } \\
\text { certified }\end{array}$ & $\begin{array}{c}\text { Utilised } \\
\text { agricultural } \\
\text { area in } \\
\text { conversion }\end{array}$ & $\begin{array}{c}\text { Organic } \\
\text { farming } \\
\text { livestock }\end{array}$ \\
\hline & \multicolumn{2}{|c|}{ AGRICULTURAL HOLDINGS } \\
\hline $\begin{array}{l}\text { Agricultural holdings without legal } \\
\text { personality }\end{array}$ & 2184 & 1330 & 41492 \\
\hline Individual agricultural holdings & 1564 & 1031 & 27734 \\
\hline $\begin{array}{l}\text { Authorised natural persons, individual } \\
\text { companies, family companies }\end{array}$ & 620 & 299 & 13758 \\
\hline $\begin{array}{l}\text { Agricultural holdings with legal } \\
\text { personality }\end{array}$ & 192 & 192 & 7185 \\
\hline
\end{tabular}

Source: Farm structure survey 2016 INSSE

Each country, regardless of the degree of economic and social development, faces problems in the balanced economic development of the territory, determined by a series of objective and subjective factors that determine the uneven development of economic areas (Istudor, 2006).

The average area of agricultural holdings in the European Union in 2013 was 16.1 ha, while the average size of organic farms (organic) was 36.7 ha.

The trend at the European level is to increase the share of organic farms in the entire farm.

Opportunities for eco-efficient intensification are also identified by better integration of farming and livestock breeding on mixed animal-farming farms (Hochman et al., 2013).

A particular feature is that organic farming management is usually young, open to innovation.

Romania has a huge potential for organic farming, yet the number of certified organic farms is quite small.

Regarding the growing demand for organic agricultural products, at the EU level, but also globally, it will lead to a significant increase in the medium and long term of agricultural land suitable for organic farming.

In fact, organic farming products have a very high added value globally, which allows good long-term economic viability of these types of agricultural holdings. 


\section{Conclusions}

The potential of Romanian agriculture is huge given the natural conditions and opportunities offered as a member state of the European Union.

The transition from the socialist economy to a competitive economy has been marked by a multitude of decisions that have created disproportions in terms of the size and economic size of agricultural holdings, especially through excessive crumbling of agricultural land.

Considering that there are several restrictions in choosing an optimal size of agricultural holdings, starting from the need to protect the natural environment to complying with the requirements imposed by crop or animal breeding technologies.

At European Union (EU-28) level, there are major differences between small and very small and large farms, respectively, at Member State level.

In terms of large-scale agricultural exploitations (between 50-100 ha and over 100 ha), France ranks first, while Cyprus last.

The particular case of the number of very small farms registered in Romania is due to the mode of ownership formation on agricultural land after 1989, the excellent fragmentation of agricultural land being obvious.

With Romania's accession to the European Union as a member state, it has resuscitated a very large part of Romanian agriculture, and the expectations of the medium and long-term Romanian economy are very closely related to the capitalization of this existing natural potential.

The structural survey in agriculture 2016 (ASA 2016) revealed changes in the structure of agricultural exploitations in Romania compared to the structural survey in 2013, as well as changes in agricultural inputs and agricultural production.

There is still an important share of very small agricultural holdings, with a self-consumption of over $50 \%$.

If we refer to organic farms, their number is still very small compared to the European Union average, but the growth potential is huge in this area due to the change in customers' perception of bio-products.

The research clearly reflects the weak role of fragmentation of agricultural land in Romania, resulting in a large number of small farms but also with poor financial potential.

Romania needs to find ways to encourage and support the free association of landowners. The financial sustainability of very small Romanian agricultural exploitations is precarious. 


\section{References}

Caron P., Bienabe E., Hainzelin E. (2014). "Making transitions towards ecological intensification of agriculture a reality: the gaps in and the role of scientific knowledge", Current opinion in environmental sustainability, Volume 8, pp. 44-52.

Gheorghe H. Popescu G.H., Istudor N., Nica E., Andrei Jean Vasile A.J., Ion R.A. (2017). "The influence of land-use change paradigm on Romania's agrofood trade competitiveness-An overview", Land Use Policy, Vol. 61, pp. 293-301.

Hochman Z., Carberry P.S., Robertson M.J., Gaydon D.S., Bell L.W., McIntosh P.C. (2013). "Prospects for ecological intensifications of Australian agriculture", European Journal of Agronomy, Volume 44, pp. 109-123.

Istudor N., Petrescu I.E. (2015). "Influence of accesing european founds for rural development over the credits for agricultural sector in Romania", Calitatea, Romanian Society for Quality Assurance, București.

Istudor N. (2006). "Dezvoltarea regională și rurală a României în condițiile integrării în Uniunea Europeană", Editura Academiei de Studii Economice, București.

Lampkin, N.H., Pearce, B.D., Leake, A.R., Creissen, H., Gerrard, C.L., Girling, R., Lloyd, S., Padel, S., Smith, J., Smith, L.G., Vieweger, A., Wolfe, M.S. (2015). "The role of agroecology in sustainable intensification", Report for the Land Use Policy Group. Organic Research Centre, Elm Farm, Hamstead Marshall.

Ponti T., Rijk B., Ittersum M.K. (2012). "The crop yield gap between organic and conventional agriculture", Agricultural Systems, Vol. 108, pp. 1-9.

Tomich T.P., Lidder P., Coley M., Gollin D., Meinzen-Dick R., Webb P., Carberry P. (2019). "Food and agricultural innovation pathways for prosperity", Agricultural Systems, Vol. 172, pp. 1-15.

Vasile A.J., Popescu C., Ion R.A., Dobre I. (2015). "From conventional to organic in Romanian agriculture - Impact assessment of a land use changing paradigm", Land Use Policy, Vol. 46, pp. 258-266.

https://ec.europa.eu/eurostat

http://www.insse.ro 